The possibility that one of the oxidative pathways in these spores may proceed through the pentosephosphate cycle remains to be proved.

We are indebted to Dr. N. K. Richtmyer, National Institutes of Health, Bethesda, Md., for suggestions and supplies of several different crystalline heptuloses and heptulosans, and to Dr. Howard Douglas, Department of Microbiology, University of Washington, for the use of the Raytheon oscillator. The support of the U.S. Public Health Service grant No. $R G-7515$ is gratefully acknowledged.

ROBERT G. BENEdICT VARRO E. TYLER, JUN. LYNN R. BraDY

Drug Plant Laboratory,

College of Pharmacy,

Department of Botany,

Daniel E. Stuntz

University of Washington,

Seattle 5, Washington.

${ }^{1}$ Kneebone, L. R., Ph.D. thesis, Pennsylvania state College (1950).

2 Bonnet, J. L., Bull. Soc. Mycol. France, 75, 215 (1959).

${ }^{3}$ Sussman, A. S., and Lingappa, B. T., Science, 130, 1343 (1959).

" Hughes, D. H., Lynch, D. L., and Somers, G. F., J. Agric. Food Chem., 8,850 (1958).

5 Rutter, L., Nature, 161, 435 (1948).

- Partridge, S. M., Biochem. J., 42, 238 (1948).

'Lemieux, R. E., and Bauer, H. F., Anal. Chem., 26, 920 (1954).

${ }^{8}$ Stewart, L. C., Richtmyer, N. K., and Hudson, C. S., J. Amer. Bourquet

envenue, A., and Williams, K. T., Arch. Biochem. Biophys., 34.

${ }^{11}$ Klevstrand, R., and Nordal, A., Acta Chem. Scand., 4, 1320 (1950).

\section{Inhibition of Dopamine $\beta$ Oxidase by Adrenalone}

WE have reported that several structural analogues of dopamine are inhibitors of dopamine $\beta$ oxidase. Dopamine $\beta$ oxidase catalyses the conversion of dopamine to norepinephrine and the enzyme activity was determined by fluorimetric estimation of norepinephrine formed, by the method of von Euler et al. ${ }^{1}$. However, when adrenalone was tested as a possible inhibitor of dopamine $\beta$ oxidase, the fluorimetric assay of norepinephrine was unsatisfactory. This was due to the fluorescence quenching of norepinephrine by adrenalone. The fluorescence quenching by other keto compounds has been reported ${ }^{2}$, and such quenching may represent a serious obstacle to the fluorimetric determination of catecholamines in the presence of ketones such as adrenalone.

Therefore, in these investigations, where adrenalone was tested as a possible inhibitor of dopamine $\beta$ oxidase, dopamine- ${ }^{14} \mathrm{C}$ was used as a substrate. The amount of dopamine ${ }^{14} \mathrm{C}$ which disappeared from the incubation mixture as well as the norepinephrine $-{ }^{14} \mathrm{C}$ formed in the incubation mixture were calculated from the radioactivity of each of these compounds. The incubation procedure as well as the separation of dopamine- ${ }^{14} \mathrm{C}$ from norepinephrine $-{ }^{14} \mathrm{C}$ was carried out as already described by us (ref. 3). The degree of the rate of inhibition of dopamine $\beta$ oxidase was determined by comparing the amount of norepinephrine- ${ }^{14} \mathrm{C}$ formed and the amount of dopamine $-{ }^{-14} \mathrm{C}$ which disappeared in an incubation mixture which contained only the substrate and in an incubation mixture which contained adrenalone and the substrate.

Table 1 shows the rate of inhibition of adrenalone on dopamine to norepinephrine conversion. For comparison, the rate of inhibition of dopamine to
Table 1. INHition of Dopamine to NOREPINEPHRINE CONVERSION

$$
\begin{array}{ccccc}
\multicolumn{4}{c}{\text { BY ADRENALONE }} \\
\text { Amount added ( } \mu \text { moles) } & \begin{array}{c}
\text { Norepinephrine } \\
\text { formed }
\end{array} & \begin{array}{c}
\text { Dopamine } \\
\text { disappearing }
\end{array} \\
1.5 & \text { none } & \text { none } & 0.60 \pm 0.06 & 0.80 \pm 0.08 \\
1.5 & \text { none } & 12 & 0.45 \pm 0.05 & \text { not estitmated } \\
1.5 & 12 & \text { none } & 0.20 \pm 0.02 & 1.2 \pm 0.1
\end{array}
$$

norepinephrine by epinine is also presented in Table $l$. It is evident that adrenalone is a more potent inhibitor of the dopamine to norepinephrine conversion than epinine.

The structure of adrenalone $(a)$ differs from epinine (b) only in that the former possesses a ketone group in the $\beta$ position.
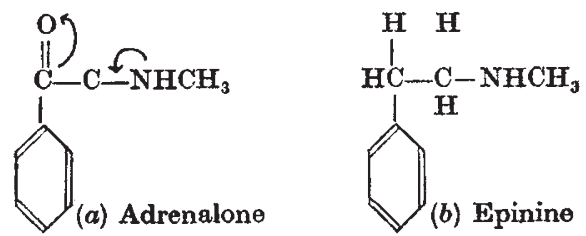

The electron-withdrawing effect of the carbonyl group in adrenalone will tend to make the nitrogen of the secondary amino group less basic. This is consistent with our previous findings that primary amines (which are weaker bases) are also stronger inhibitors of dopamine $\beta$ oxidase ${ }^{3}$. A second possibility is that the electrophilic centre of adrenalone interacts with the nucleophilic centre on the enzyme surface.

It should be stressed that while epinine itself is also a substrate of dopamine $\beta$ oxidase and its inhibition of dopamine to norepinephrine conversion is due to a substrate competition, it is more likely that adrenalone is a non-competitive inhibitor.

This work was supported by grants from the National Institutes of Health.

M. Golostein

J. F. CONTRERA

Department of Psychiatry and Neurology, New York University College of Medicine.

'von Euler, U. S., and Floding, I., Acta Physiol. Scand., 33, 45 (1955). 2 van Duuren, B. L., J. Organic Chem, (in the press).

${ }^{3}$ Goldstein, M., and Contrera, J. F., Experientia, 17, 267 (1961).

\section{Acidic Dissociation of 7 : 9-Dialkylguanines and its Possible Relation to Mutagenic Properties of Alkylating Agents}

Watson and Crick ${ }^{1}$ proposed as a possible mechanism for mutation that changes in the tautomeric structure of a base of deoxyribonucleic acid (DNA) could induce its pairing with an anomalous base. In considering the possible correlation between the action of alkylating agents on DNA and the mutagenic activity of these agents, we mentioned in a recent report ${ }^{2}$ that it was not obvious how the initial action of alkylation of DNA, which has been shown to occur at $N_{(7)}$ of guanine moieties ${ }^{3,4}$, could affect base-pairing in DNA according to the Watson-Crick model. We therefore suggested that the subsequent loss of the alkylated guanine moiety from DNA (refs. 4 and 5) might be the chemical action necessary for mutation to result.

We now wish to present preliminary evidence that alkylation of guanine nucleosides or other 9-substituted guanines at $\mathbf{N}_{(7)}$ results in an immediate change in the molecular structure of these bases at neutral $p \mathbf{H}$ in that part of the molecule involved in hydrogen. 